JERZY WYROZUMSKI

\title{
ARCYBISKUPI GNIEŹNIEŃSCY XIII I XIV WIEKU
}

Mój przegląd dokonań arcybiskupów gnieźnieńskich zamyka się w ramach czasowych 1199-1382 r. Sa to dwie jasne cezury chronologiczne pierwsza z nich stanowi początek arcybiskupich rządów Henryka Kietlicza, druga datę śmierci arcybiskupa Jana Suchywilka. Maja one charakter par excellence umowny, ale jeżeli je przetłumaczyć na język faktów i realiów historycznych, okażą się w wysokim stopniu zasadne. Współczesny bowiem wielkiemu papieżowi Innocentemu III Henryk Kietlicz był inicjatorem i głównym protagonistą dogłębnej reformy Kościola polskiego, Jan Suchywilk byl ostatnim nieugiętym rzecznikiem politycznego programu Kazimierza Wielkiego w sprawie następstwa tronu w Polsce; zmarł niespełna pół roku wcześniej od Ludwika andegaweńskiego, a więc z nim razem zamykał okres unii personalnej polsko-węgierskiej. Wielkiemu politycznemu przełomowi, który wyraził się w koronacji Jadwigi na króla Polski i utworzeniu unii Polski z Litwa, statystowal już następca Suchywilka na tronie arcybiskupim, Bodzęta. Formację polityczną wyniósł wszakże z czasów Kazimierza Wielkiego, którego byl bliskim współpracownikiem i doradca, ale jako arcybiskup inicjował już wielkie dzieło chrystianizacji Litwy przez Polskę i tworzenia organizacji kościelnej na Litwie, a mial zapewne również swój udział w kształtowaniu ustrojowej formy wspólistnienia dwu połączonych przez osobę władcy państw. Może więc być lączony już z Polska jagiellońską.

Lata 1199-1382, stanowiące ramy chronologiczne niniejszego artykulu, odpowiadają dwu wielkim epokom w dziejach politycznych i społeczno-ustrojowych Polski, a to, co lączyło się z polską państwowością, miało bardzo istotne odniesienia do dziejów arcybiskupstwa gnieźnieńskiego, tak dalece, że niekiedy trudno rozdzielić te dwa składniki naszej narodowej przeszłości. Wypada stwierdzić przypadkowa, ale ważną zbieżność między powołaniem na tron arcybiskupi Henryka Kietlicza a ostatecznym załamaniem się pryncypatu w Polsce. Najpierw podważono seniorat, gdy wladzę pryncypacką objał 
Kazimierz Sprawiedliwy (około 1177 r.), następnie nadano dzielnicy krakowskiej - wbrew statutowi sukcesyjnemu Bolesława Krzywoustego - charakter dziedziczny, a uczynił to w końcu XII w. sam Mieszko Stary, chcac ocalić pryncypat, wreszcie śmicrć Mieszka Starego w 1202 r. przypieczętowała stan, w którym poszczególne księstwa piastowskie stały się faktycznie niezależne, a sporadyczne próby restytucji w całości lub w części zasad sukcesyjnych stworzonych przez statut Krzywoustego byly bez szans. Tak więc zaczą się okres pelnego rozbicia dzielnicowego Polski. W jego zamknięciu uczestniczył czynnie arcybiskup Jakub Świnka i wielkie mial na tym polu zasługi. Wspomnieć należy choćby tylko dwa fakty o silnej wymowie symbolicznej koronacji Przemysła II i Wackawa II, obu przez niego dokonanych. Po tej epoce rozbicia nastala druga, łącząca się z tworzeniem zrębów politycznej jedności Polski i umacnianiem na różnych polach jej wewnętrznej budowy i zewnętrznego prestiżu. W tym dziele wielki był udział Kościoła polskiego, a jako czołowa postać na rozległym polu polityczno-prawnych dokonań rysuje się nam przede wszystkim arcybiskup Jarosław ze Skotnik Bogoria. Cezura wewnętrzna dwu epok przypada bezsprzecznie na czasy Jakuba Świnki i nie przypadkowo łączy się z jego osobą. Kładziemy ją prawie dokładnie na połowę jego arcybiskupich rządów, tj. na rok 1300. Symbolicznie przynajmniej wyznacza ją koronacja Wacława II.

W calym interesujacym nas tu okresie lat 1199-1382 zasiadało faktycznie na gnieźnieńskim tronie arcybiskupim dziewięciu arcybiskupów: Henryk Kietlicz w latach 1199-1219, Wincenty z Niałka 1220-1232, Pełka 12321258, Janusz h. Tarnawa 1258-1271, Jakub Świnka 1283-1314, Borzysław 1314-1317, Janisław 1317-1341, Jarosław ze Skotnik Bogoria 1342-1374 i Janusz Suchywilk 1374-1382. Obok tego rejestru należy wymienić Iwona Odrowąża, biskupa krakowskiego po mistrzu Wincentym Kadlubku, który w 1219 r. otrzymał nominację papieską na arcybiskupstwo gnieźnicńskie, alc jej nie przyjąl ${ }^{1}$. Następnie należy zauważyć długi, trwający 12 lat wakans między Januszem $h$. Tarnawa a Jakubem Świnką. Na pewno w czasie tego wakansu otrzymał w $1278 \mathrm{r}$. z rąk papieża Mikołaja III prowizję na arcybiskupa gnieźnieńskiego dominikanin, penitencjariusz i kapelan papicski, glośny autor Kroniki papieży i cesarzy, Marcin Polak z Opawy. Już jednak w roku następnym zmarł $\mathrm{w}$ Bolonii w drodze do Polski, zanim jeszcze zdolal objąc nadane mu stanowisko ${ }^{2}$. Co do okresu poprzedzającego tę nominację, mamy mglista i mało wiarygodna tradycję Jana Długosza, iż kapituła gnieźnicńska wybrala na miejsce Janusza $h$. Tarnawa swego prepozyta Filipa, który nie

\footnotetext{
${ }^{1}$ R. Grodecki, Iwo Odroważ. W: PSB. T. 10:1962-1964, s. 187-192.

${ }^{2}$ K. Grodziska-Ożóg, Marcin Polak i jego twórczość. „Nasza Przeszłość”. T. 58:1982, s. 169-201.
} 
otrzymał konfirmacji ze strony Stolicy Apostolskiej ${ }^{3}$. Wiadomo natomiast na pewno, że w 1273 r. ta sama kapituła dokonała niezgodnego wyboru: prepozyta Konrada i kanonika Jana Radlicy ${ }^{4}$. Zapewne ta niezgodność sprawiła, że żaden $z$ elcktów nie został zatwierdzony, a archidiecezją administrowali kolejno Wolimir biskup kujawski i Prokop kantor gnieźnieński. Natomiast po Marcinie Polaku z Opawy kapituła gnieźnieńska wybrała na arcybiskupa swego kanonika Włościbora, który mimo uzyskanej konfirmacji papieskiej zrzekł się godności ${ }^{5}$. W tej sytuacji papież Marcin IV powołał na arcybiskupstwo gnieźnieńskie w $1281 \mathrm{r}$. franciszkanina Henryka de Bren ${ }^{6}$. Ten również godności nie przyją.

Co można powiedzieć o arcybiskupach gnieźnieńskich interesującego nas tu okresu pod względem ich pochodzenia, wykształcenia, wcześniejszej kariery i wieku, w jakim godność arcybiskupią osiagnęli i ją piastowali?

Zacznijmy od pochodzenia: Henryk Kietlicz wywodził się prawdopodobnie $z$ rodziny łużyckiej lub czeskiej, która w nieznanym bliżej czasie przybyła do Wielkopolski ${ }^{j}$. Przedstawicielem tej rodziny był z pewnościa inny Henryk Kietlicz, zwiazany $z$ Mieszkiem Starym ${ }^{8}$. Arcybiskup Wincenty pochodzil jak to już dawno wykazano $-\mathrm{z}$ wielkopolskiego rodu rycerskiego JeleniNiałków ${ }^{9}$, Pełka - z rycerstwa małopolskiego (wieś Kwilina koło Jędrzejowa), prawdopodobnie $z$ rodu Półkoziców, jak na to wskazuje kryterium imionowe ${ }^{10}$, Janusz - jeżeli zaufać późniejszej tradycji - z rodu Tarnawów, którego gniazdo znajdowało się w ziemi sandomierskiej; myli się natomiast Jan Długosz, łącząc go z Grzymalitami ${ }^{11}$. Jakub Świnka pochodził $z$ rycerskiego rodu Świnków, osiadłego na Śląsku i z kolei także na Kujawach i w zicmi sieradzkiej, z której właśnie wyszedł arcybiskup ${ }^{12}$. Jego nastẹpcẹ Borzysława łączy

${ }^{3}$ J. Długosz, Vitae episcoporum Poloniae, Opera omnia. T. 1. Kraków 1887, s. 354.

${ }^{4} V M P$ I, nr 84.

${ }^{5}$ VMP I, nr 86, 88, 89 .

${ }^{6} \mathrm{KDW}$ l, nr 470; por. T. Silnicki, K. Gołąb, Arcybiskup Jakub Świnka i jego epoka. Warszawa 1956, s. 24-26.

${ }^{7} \mathrm{~J}$. Umiński, Henryk arcybiskup gnieznienski zwany Kietliczem, s. 3; K. Tymieniecki, Henryk zwany Kietlicz. W: PSB. T. 9:1960-1961, s. 415-417.

${ }^{8}$ MPH II, s. 835 .

${ }^{9}$ J. Umiński, Arcybiskup Wincent z Nialka następca Henryka zw. Kietliczem. W: Księga pamiqtkowa ku czci Wladyslawa Abrahama. T. 2. Lwów 1931, s. 141-166; S. Kozierowski, Ród Jeleni-Nialków-Brochwiczów (Studia nad pierwotnym rozsiedleniem rycerstwa wielkopolskiego VII). Poznań 1918, nie notuje go wśród rozpoznanych członków rodu.

${ }^{10}$ J. Bieniak, Pelka. W: PSB. T. 25:1980, s. 574-577.

${ }^{11}$ J. Nowacki, Arcybiskup gnieźnieński Janusz i nieznany synod prowincjonalny roku 1258. „Collectanea Theologica”. T. 14:1933, s. 92-172, zob. s. 101, 113-114.

${ }^{12}$ T. Silnicki, K. Gołąb, Arcybiskup Jakub Świnka.., s. 39-42. 
tradycja $z$ wielkopolskim rodem Bylinów ${ }^{13}$. Janisława wywodzi Jan Długosz z rycerskiego rodu Korabitów, rozsiedlonego w ziemi sieradzkiej i w południowej Wielkopolsce ${ }^{14}$. Jarosław ze Skotnik pochodził z rodu Bogoriów, którego gniazdo znajdowało się w ziemi sandomierskiej i który już wcześniej doszedł do znaczenia; ojciec Jarosława Piotr był wojewoda krakowskim w czasach Leszka Czarnego i on prawdopodobnic zapewnił swemu rodowi wysoka range w hierarchii społecznej ${ }^{15}$. Wreszcie Jan Suchywilk należał do rodu Grzymalitów, który odegrał dużą rolę w Wiclkopolsce w okresie andegaweńskim; był bratankiem starosty wielkopolskiego Domarata i krewniakiem swego poprzednika na stolicy arcybiskupiej Jarosława Bogorii ${ }^{16}$.

Jak widać, nie zawsze pochodzenie z możnowładczego rodu stwarzało tytuł do godności arcybiskupiej. W większości wypadków wywodzili się arcybiskupi interesującego nas okresu z rycerstwa średniego. Tym bardziej musiało się liczyć wykształcenie. Niestety nie zawsze możemy je należycie rozpoznać. Co do Henryka Kietlicza, można się tylko domyślać, że kształcił się na Zachodzie. Wincenty z Niałka, jeżeli słusznie jest identyfikowany z Wincentym kanclerzem Władysława Laskonogiego, musiał być wykształcony ${ }^{17}$. O wykształceniu Pełki nic nie można powiedzieć, ale uznanie, jakim się cieszyl i szereg niełatwych politycznych dokonań każą dopatrywać się u niego dobrej intelektualnej formacji. Jego następca Janusz był scholastykiem łęczyckim, przez dwadzieścia lat kanclerzem arcybiskupa Pelki i przez sześć lat piastował kanclerstwo u księcia Kazimierza kujawsko-łęczycko-sieradzkiego ${ }^{18}$. Te funkcje mogła spełniać tylko osoba dobrze wykształcona. O studiach Ja-

${ }^{13}$ Por. J. Nowacki, Borzyslaw. W: PSB. T. 2:1936, s. 370-371; S. Kozierowski, Ród Bylinów. Lwów 1913, nie notuje go wśród rozpoznanych członków tego rodu; J. Długosz, Vitae, s. 357, zalicza go do rodu Labędziów; M. Friedberg, Ród Labędziów w wiekach srednich. Kraków 1925, nie podjał tego zagadnienia; J. Bieniak dopuszcza możliwość jego pochodzenia $\mathrm{z}$ rodu Korabitów.

14 J. Długosz, Vitae, s. 358; S. Kozierowski, Ród Korabitów. Łomża 1933, nie notuje go wśród rozpoznanych czlonków rodu; J. Bieniak łączy z nim herb Jabłoń i wywodzi go z ziemi sieradzkiej.

${ }^{15}$ Z. Wdowiszewski, Ród Bogoriów w wiekach średnich. „Rocznik Polskiego Towarzystwa Heraldycznego we Lwowie". T. 9:1930, s. 1-96, zob. rozdz. IV.

${ }^{16}$ Katalog arcybiskupów gnieźnieńskich., W: MPH. T. 3, s. 396: Iste nobilis de terra Sandomiriensi de domo Grzimala et de domo Strzelcze prope Paczanow circa fluvium Schodna, dictus Schuchiwilk fuitque germanus ex sorore nepos domini laroslai immediati sui predecessoris. - J. Długosz, Annales seu cronicae incliti Regni Poloniae, lib. IX. Warszawa 1978, s. 347: Johannes de Strzelcze vocatus Suchiwilk Grzimalita.

17 J. Umiński, Arcybiskup Wincent z Nialka.

${ }^{18}$ J. Nowacki, Arcybiskup gnieznieński Janusz, s. 101-107; J. Mitkowski, Kancelaria Kazimierza Konradowica księcia kujawsko-łęczyckiego (1233-1267). Wrocław-WarszawaKraków 1968, s. 50+52. 
kuba Świnki nie wiemy nic; dziwi tylko, że osiagnął w kapitule gnieźnieńskiej prałacką godność kantora bez święceń kapłańskich, zaledwie jako diakon ${ }^{19}$. Borzyslaw był na pewno wykształcony, skoro pełnil funkcje kanclerza u księcia mazowieckiego Bolesława ${ }^{20}$. Zapewne za granica uzyskał wykształcenie Janisław. Być może był dekretystą, skoro papież powołał go obok biskupa poznańskiego Domarata i opata mogilskiego Mikolaja, na sędziego w procesie Polski z Zakonem $(1320)^{21}$. Uformowanym w Bolonii doktorem dekretów i tamże syndykiem Uniwersytetu ultramontanów (przed 1322 r.) był Jarosław ze Skotnik Bogoria ${ }^{22}$. Tamże doktorat dekretów uzyskał również jego krewniak i następca na arcybiskupstwie Janusz Suchywilk ${ }^{23}$.

Co do wicku poszczególnych omawianych tu arcybiskupów brak nam $\mathrm{z}$ reguły dostatecznych informacji. Tylko o Jarosławie Bogorii możemy powiedzieć, że - jeżeli prawdziwa jest tradycja, iż umierając w 1376 r. miał sto lat $^{24}$ - to musiał osiągnąc godność arcybiskupią w wieku 65 lat, a Janusz Suchywilk - jeżeli się urodził około 1310 r. - to również w takim samym mniej więcej wieku. Nie wiadomo, jaką godność miał przed osiagnięciem arcybiskupstwa Henryk Kietlicz. Wincenty z Niałka był już przynajmniej w 1208 r. kanclerzem Laskonogiego, a w 1213 r. zasiadał w kapitule gnieźnieńskiej ${ }^{25}$. Pełka wzmiankowany jest $w$ latach 1213-1229 jako kantor gnieźnieński ${ }^{26}$. Janusz był w latach 1232-1252 kanclerzem gnieźnieńskim, a w latach 1252 1258 kanclerzem księcia Kazimierza kujawsko-lęczyckiego; w 1243 r. występuje jako dziekan gnieźnieński, w $1250 \mathrm{r}$. jako scholastyk łęczycki i w $1255 \mathrm{r}$. jako proboszcz kapituly gnieźnieńskiej ${ }^{27}$. O Jakubie Śwince wiadomo, że jako diakon był prawdopodobnie przed r. 1271 kanonikiem zwykłym kapituły gnieźnieńskiej i z kolei około $1280 \mathrm{r}$. jej kantorem ${ }^{28}$. Borzysław miał przynajmniej w 1298 r. godność kanonika gnieźnieńskiego, a wnet potem został archidiakonem poznańskim. W $1311 \mathrm{r}$. spotykamy go jako kanclerza księcia

${ }^{19}$ T. Silnicki, K. Gołąb, Arcybiskup Jakub Swinka..., s. 36-37.

${ }^{20}$ J. Nowacki, Borzysław. W: PSB.

${ }^{21}$ Lites ac res gestae inter Polonos Ordinemque Cruciferorum. T. 1. Wyd. H. Chłopocka. Wrocław-Warszawa-Kraków 1970, s. 3.

${ }^{22}$ Z. Kowalska-Urbankowa, Jaroslaw ze Skotnik Bogoria arcybiskup gnieźnieński, prawodawca i dyplomata (zm. 1376) „Nasza Przeszlość”. T. 63:1985, s. 53-96, zob. s. 55.

${ }^{23}$ J. Lojewska, Arcybiskup Suchywilk w historii Kościola w Polsce. „Collectanea Theologica". T. 20:1939, s. 1-58; A. Strzelecka, Janusz Suchywilk. W: PSB. T. 10, 1962 1964, s. 583-585.

${ }^{24}$ Taką wiadomość podal Janko z Czarnkowa. W: MPH. T. 2, s. 672; K. Jasiński kwestionuje zasadność tej informacji.

${ }^{25}$ J. Umiński, Arcybiskup Wincent z Nialka.

${ }^{26}$ J. Bieniak, Pelka. W: PSB.

27 J. Nowacki, Arcybiskup gnieźnieński Janusz.

${ }^{28}$ T. Silnicki, K. Gołąb, Arcybiskup Jakub Swinka..., rozdz. II. 
Bolesława mazowieckiego ${ }^{29}$. O Janisławie wiemy, że zanim został arcybiskupem był archidiakonem gnieźnieńskim, a już jako arcybiskup był przynajmniej w latach 1324-1325 kolektorem świętopietrza ${ }^{30}$. Jarosław Bogoria był kanclerzem biskupa krakowskiego Nankera, archidiakonem krakowskim, kanonikiem włocławskim i gnieźnieńskim oraz kanclerzem kujawskim ${ }^{31}$. Jan Suchywilk wreszcie był notariuszem (1336) i kapelanem królewskim, kanonikiem poznańskim, włocławskim i krakowskim, proboszczem gnieźnieńskim, a od 1355 r. kanclerzem krakowskim (praktycznie królewskim) ${ }^{32}$.

Poszczególne pontyfikaty arcybiskupie $\mathrm{w}$ interesujacym nas okresie przedstawialy się następująco: Henryk Kietlicz 20 lat, Wincenty z Nialka 12 lat, Pełka 26 lat, Janusz h. Tarnawa 13 lat, Jakub Świnka 31 lat, Borzysław 3 lata, Janisław 24 lata, Jarosław Bogoria 32 lata i Jan Suchywilk 8 lat. Większość z nich miała zatem dostatecznie dużo czasu, aby rozwinąć należycie swoją arcybiskupią działalność.

Arcybiskup byl w średniowieczu nie tylko zwierzchnikiem prowincji kościelnej, ale także najwyższej rangi mężem stanu. Pomijam tu tytularne godności arcybiskupie, nadawane zwłaszcza we Włoszech. Nie ulega zatem watpliwości, że rolę interesujących nas tu dostojników należy rozpatrywać na dwu płaszczyznach: kościelnej i politycznej. Trzeba zarazem pamiętać o komplikacjach, jakie się w Polsce ujawniły we wzajemnych relacjach obu tych płaszczyzn. Wiadomo mianowicie, że utworzona w r. 1000 polska prowincja kościelna pokrywała się pierwotnie z terytorium państwowym ówczesnej monarchii piastowskiej. Byla to relacja bardzo racjonalna, zapewniająca Kościołowi efektywność dzialania, a władzy państwowej silne wsparcie ze strony czynników kościelnych. Kościół stawał się równocześnie siłą integrująca społeczeństwo podporządkowane monarchii, współtworzył jedność polityczno-kulturalną, razem z władzą państwową ksztaltował wspólnotę narodową. Ten model wspóldziałania został naruszony w interesującym nas okresie w sposób dwojaki: po pierwsze zniknęła jedność polityczna państwa, po drugie pewne jego terytoria, należące do polskiej prowincji kościelnej, przeszły pod obca zwierzchność polityczna, a inne - mam na uwadze Ruś halicko-wlodzimierską - do prowincji tej nie należące weszły w związek polityczny z Polską. Ta zmieniająca się sytuacja wymagała od Kościola polskiego dużcj elastyczności działania i mądrości politycznej od jego głowy, gdy praca duszpasterska i kościelno-administracyjna zderzała się z rzeczywistością polityczna, gdy państwowość polska wchodzila na trudne wiraże dziejów.

${ }^{29}$ J. Nowacki, Borzyslaw. W: PSB.

${ }^{30}$ J. Długosz, Annales, lib. IX, s. 43; MPV I, nr 92, 105, 140.

${ }^{31}$ Z. Kowalska-Urbankowa, Jarostaw ze Skotnik..., rozdz. I.

${ }^{32}$ J. Lojewska, Arcybiskup Suchywilk... 
Zatrzymam się najpierw nad epoką rozbicia dzielnicowego Polski. Był to okres, który w pewnym sensie sprzyjał umocnieniu pozycji Kościola. W walce o immunitet dla dóbr kościelnych, o rozszerzenie stanu posiadania, o likwidację uciążliwych praw książęcych, o suwerenność władz kościelnych itp. łatwiej było się uporać z pojedynczymi często słabymi książętami, niż by to przyszło w odniesieniu do jednego silnego monarchy. Być może stanowiło to okoliczność dla Kościoła sprzyjającą. Z drugiej wszakże strony podziały polityczne zagrażaly nader często jego stanowi posiadania, gdy między książętami wybuchały konflikty. Dochodziło już nie tylko do utrudnień w administrowaniu dóbr pozostających pod różnymi wladztwami, ale często do świadomej ich dewastacji. Znamy np. rejestr ogromnych szkód (1238) zadanych posiadłościom biskupstwa włocławskiego w wyniku najazdu księcia pomorskiego Świętopełka na państwo Konrada mazowieckiego ${ }^{33}$ i podobny rejestr szkód biskupstwa wrocławskiego (1271), będących wynikiem najazdu na Śląsk księcia krakowskiego Bolesława Wstydliwego ${ }^{34}$.

Wśród pięciu arcybiskupów gnieźnieńskich XIII w. trzech na pewno odegrało w skali dziejów Polski bardzo ważną rolę. Pierwszy z nich w porządku chronologicznym, Henryk Kietlicz, zaznaczył się przede wszystkim jako wytrwały i konsekwentny reformator Kościola polskiego, kolejny z tej trójki, Pełka, zasłużył się godnie - oprócz kontynuacji i utrwalania reformy - szeregiem wysiłków zmierzających środkami kompromisu do utrzymania pokoju wśród księstw dzielnicowych Polski. Trzecia wybitna postać na stolicy arcybiskupiej gnieźnieńskiej to niewątpliwie Jakub Świnka, którego tradycja łączy silnie z procesem zjednoczeniowym ziem polskich.

Działalność Henryka Kietlicza nie znalazła odbicia w przeddługoszowej tradycji historiograficznej. Ocenił ją dopiero w sposób dość trafny Jan Dłu$\operatorname{gosz}^{35}$. Zachowało się natomiast kilkadziesiąt listów papieża Innocentego III i Honoriusza III oraz parę przywilejów książęcych, które ją oświetlają w sposób nie budzący żadnych wątpliwośsi ${ }^{36}$. Z dużym prawdopodobieństwem odniesiono również do jego czasów statut synodu kamieńskiego ${ }^{37}$. Najogólniej rzecz ujmując, program Henryka Kietlicza sprowadzał się do walki o liberta-

${ }^{33}$ Zbiór ogólny przywilejów i spominków mazowieckich. Wyd. J.K. Kochanowski. Warszawa 1919 , nr 379.

${ }^{34}$ Urkunden zur Geschichte des Bisthums Breslau. Wyd. G.A. Stenzel. Wrocław 1845, $\operatorname{nr} 36$.

35 J. Długosz, Vitae, s. 350-352.

${ }^{36} K D W$ I, nr 38, 39, 41-52; 55-62, 67, 68, 70-72, 74-76, 85-92, 96, 98, 102, 103, 105; VMP I, nr 2, 4, 8, 9, 13, 17, 19; MPV I, nr 7, 10; KDM I, nr 5-7.

${ }^{37}$ Statuty synodalne Henryka Kietlicza. Oprac. A. Vetulani, uzup. Z. Kozłowska-Budkowa. Kraków 1938. 
tem ecclesiasticam, tj. o emancypację Kościoła polskiego spod władzy świeckiej, o jego suwerenność. Chodziło mianowicie o zapewnienie wyboru biskupów przez kapituły w miejsce dotychczasowych nominacji książęcych, czyli o obalenie świeckiej inwestytury dostojników kościelnych, o wprowadzenie immunitetu skarbowego i sądowego w dobrach kościelnych, o zniesienie tzw. ius spolii czyli prawa władców do zagarniania ruchomości po zmarlych biskupach, o pozyskanie tzw. privilegium fori, czyli przywileju własnego kościelnego sądownictwa dla osób duchownych, o oddzielenie synodów kościelnych od zjazdów państwowych czyli wieców, wreszcie o solidarne stanowisko duchowieństwa wobec władzy świeckiej. W programic wewnątrzkościelnym znalazl się celibat duchownych, wciąż jeszcze nie przestrzegany, mimo nakazu legata papieskiego Piotra z Kapui, który bawil w Polsce w 1197 r. ${ }^{38}$

Świecką inwestyturę biskupów udało się przełamać najpierw w diecezji wroclawskiej, gdzie w 1201 r. został wprowadzony na tron biskupi, w drodze tzw. postulacji, Cyprian, dotychczasowy biskup lubuski ${ }^{39}$, a następnie w diecezji krakowskiej, gdzie w r. 1207 po biskupie Pelce dokonano faktycznie wyborów kanonicznych. Wprawdzie biskupstwo otrzymał tutaj nie elekt większości, biskup płocki Gedko, ale elekt mniejszości, mistrz Wincenty Kadłubek, którego aprobował książę Leszek Bialy ${ }^{40}$, jednak zasada elekcyjności stała się już faktem i odtąd przecierała sobie drogę także w innych diecezjach.

Niewątpliwym sukcesem Henryka Kietlicza byly pozyskane przez niego pierwsze generalne przywileje immunitetowe dla Kościoła polskiego. Pierwszy taki przywilej wystawili w 1210 r. książęta Leszek Biały, Konrad mazowiccki i Władysław Odonic ${ }^{41}$, drugi w 1215 r. - Leszek Biały, Konrad mazowiecki, Wladysław Odonic i Kazimierz opolski ${ }^{42}$. Pierwszy z nich znosił ius spolii. Jest rzeczą znamienna, że dla swego programu pozyskał sobie Henryk Kietlicz młodszych książąt, gdy starsi, a zwłaszcza główny antagonista arcybiskupa Wladysław Laskonogi, trwali jeszcze na dawnych pozycjach.

W historiografii naszcj istnicje rozbicżność zdań co do tego, czy Henryk Kietlicz faktycznie zdołał wywalczyć dla Kościoła polskicgo privilegium fori, zgodnie z przekazem Długosza ${ }^{43}$. Przychylam się do poglądu, że nie, że natomiast uczynił to, co bylo w zakresic jcgo możliwości, tzn. zakazal duchownym

${ }^{38}$ J. Zieliński, Legacja Piotra z Kapui do Czech i Polski w 1197 r. "Collectanea Theologica". T. 3-4:1957, s. 576-597.

${ }^{39}$ T. Silnicki, Historia Ślaska. T. 2. Kraków 1939, s. 51-53.

${ }^{40}$ R. Grodecki, Mistrz Wincenty Kadlubek biskup krakowski. „Rocznik Krakowski” 19:1923 i osobna odbitka, s. 20-22; por. też KDKK I, nr 7.

${ }^{41} K D M \mathrm{I}, \mathrm{nr} 7$.

${ }^{42} K D K K$ I, nr 10.

${ }^{43}$ J. Długosz, Vitae, s. 351. 
pozywać się przed sądy świeckie ${ }^{44}$. Faktycznie własne sądownictwo dla duchownych Kościół polski mial w połowie XIII w., z wyłączeniem tzw. quaestiones hereditariae, czyli spraw o dziedziczenie dóbr własnych nie będących benefícjami, które $z$ natury rzeczy podlegały sądom świeckim (później ziemskim).

Bardzo spektakularnym sukcesem Henryka Kietlicza bylo powierzenie mu przez Stolicę Apostolska w 1210 r. opieki nad misją Prus ${ }^{45}$, którą podjął klasztor cystersów w Leknie: najpierw jego opat Gotfryd $(1206)^{46}$, a potem mnich Chrystian, powołany na biskupa misyjnego $w$ tym pogańskim jeszcze kraju w 1215 lub 1216 r. ${ }^{47}$ Udział Henryka Kietlicza z sześcioma biskupami polskimi w IV soborze lateraneńskim ${ }^{48}$, oraz trzy lub cztery odbyte przez niego synody prowincjonalne ${ }^{49}$, dopełniają sukcesów tego pontyfikatu.

O dokonaniach następcy Henryka Kietlicza na tronie arcybiskupim, Wincentego $z$ Niałka, wiemy niewiele. W dwunastoletnim okresie jego rządów nie było synodu prowincjonalnego, nie kontynuowano też zapewne dzieła reform. Wincenty był wszak wcześniej kanclerzem Wladysława Laskonogiego, głównego przeciwnika Kietlicza ${ }^{50}$. Ale w 1232 r. rozpoczął się dwudziestosześcioletni pontyfikat arcybiskupi Pełki. Odbyły się w jego okresie przynajmniej cztery synody $(1233,1248,1250,1257)^{51}$, okrzepła „wolność Kościola”. Osobiste przymioty arcybiskupa przyniosty wzrost autorytetu Gniezna. Dzięki licznym nadaniom i przywilejom na rzecz arcybiskupstwa i poszczególnych biskupstw umocniła się pozycja materialna Kościola polskiego ${ }^{52}$. Specjalne przywileje kościelne, pozyskane przez Pełkę od Stolicy Apostolskiej świadczą, że i w niej cieszył się uznaniem ${ }^{53}$. Był aktywnym uczestnikiem soboru odby-

${ }^{44}$ Podstawę źródłową tego poglądu stanowi statut synodu przypisanego Kietliczowi. W: Statuty synodalne. Oprac. A. Vetulani, s. 12; R. Grodecki, O charakterystykę Kietlicza. „Kwartalnik Historyczny”, R. 44:1930, t. II - „Wiadomości Historyczne”, Z. 1, s. 21-43, zob. s. 26; por. też W. Abraham, Privilegium fori w ustawodawstwie Kościola polskiego $w$ wieku XIII. „Collectanea Theologica”. T. 17. 1936, s. 1-16.

${ }^{45} \mathrm{KDW}$ I, nr 67.

${ }^{46}$ Tamże, nr 39; por. M. Lodyński, Opat Gotfryd i biskup Chrystian. „Kwartalnik Historyczny". R. 24:1910, s. 98-120; K. Tymieniecki, Misja polska w Prusach i sprowadzenie krzyżaków. Torun 1935, s. 19; T. Manteuffel, Papiestwo i cystersi. Warszawa 1955, s. $97-100$

${ }^{47}$ T. Manteuffel, Papiestwo..., s. 104.

${ }^{48} \mathrm{~J}$. Umiński, Henryk arcybiskup gnieźnieński, s. 149-157.

${ }^{49}$ Statuty synodalne. Wyd. A. Vetulani. Dodatek Z. Kozłowskiej-Budkowej, s. 47-48.

${ }^{50} \mathrm{~J}$. Umiński, Arcybiskup Wincenty z Nialka.

${ }^{51} K D W$ I, nr 150, 274, 361, 596.

${ }^{52}$ Por. np. KDW I, nr 174, 234.

${ }^{53}$ Por. zwłaszcza tamże, nr 210, 266. 
tego w 1245 r. w Lyonie ${ }^{54}$, przyczynił się niewatpliwie do kanonizacji św. Stanisława $^{55}$. Na szczególną uwage zasluguje bulla papieża Aleksandra IV z 1256 na rzecz Kościoła polskiego, zatwierdzająca odrębny status polskiej prowincji kościelnej, która miała być proprio vacabulo Polonia insignita i pozostawać w szczególności niezależna od legatów papieskich na teren Nie$\operatorname{miec}^{56}$. Była ona niewatpliwym osiagnięciem Pełki.

Trzeba wreszcie zwrócić uwagę na rolę polityczną tego dostojnika kościelnego. W szczytowym okresie rozbicia dzielnicowego Polski, zatraty horyzontów politycznych u poszczególnych książą, w okresie licznych waśni i konfliktów między nimi jawi się on nam jako szczęśliwy mediator. Przyczynił się do zakończenia długotrwałej wojny Świętopełka pomorskiego z Zakonem i do zawarcia przez strony pokoju na Kowalowym Ostrowie ${ }^{57}$, do rozstrzygnięcia szereg lat trwającego sporu między synami Władysława Odonica Przemysłem I i Bolesławem Pobożnym, a zatem do podziału między nich dzielnicy wielkopolskiej (1247-1253) ; $^{58}$; Pelka interweniował w sporach kościelno-politycznych księcia kujawskiego Kazimierza z biskupem włoclawskim Michałem (1250) i księcia legnickiego Bolesława Rogatki z biskupem wrocławskim Tomaszem $\mathrm{I}^{59}$.

Nie dorównywał już Pełce jego następca na stolicy arcybiskupiej Janusz h. Tarnawa, chociaż na jego stosunkowo krótki pontyfikat przypadają przynajmniej 4 synody $(1258,1262,1267 \text { bis) })^{60}$. Musial się więc troszczyć o stan Kościoła polskiego, w tym prawdopodobnie o jego warunki materialne. Pewna osobliwością było odbycie synodu prowincjonalnego w Dankowie, w tym samym roku, w którym odbył się synod wrocławski legata papieskiego Gwidona, jak gdyby dla osobnego omówienia jego efektów ${ }^{61}$.

Wielką indywidualnością na tronie arcybiskupim był po dwunastoletnim wakansie Jakub Świnka. Na pewno przejąl arcybiskupstwo w stanie dewastacji, ale niewiele wiemy o jego działaniach gospodarczych. Żywo natomiast interesował się sprawami polskiej prowincji kościelnej, o czym świadczy aż sześć odbytych za jego pontyfikatu synodów prowincjonalnych $(1285,1287$,

${ }^{54}$ Rocznik kapituly gnieźnieriskiej. W: MPH seria П. T. 6:1962, s. 8.

${ }^{55}$ Podnoszą to Katalog arcybiskupów gnieźnieńskich. W: MPH. T. 3, s. 393, oraz J. Długosz, Vitae, s. 352-353.

${ }^{56} \mathrm{KDW}$ I, nr 343.

${ }^{57}$ Preussisches Urkundenbuch. T. 1. Wyd. R. Philippi. Königsberg 1882, nr 194.

${ }^{58}$ Kronika wielkopolska. W: MPH seria II. T. 8(2), 1970, s. 99.

${ }^{59} D K i M$, s. $184-188$ (nr 13); $M P H$ seria II. T. 8(2), s. 109-110; KDW I, nr 361.

${ }^{60}$ J. Nowacki, Arcybiskup gnieźnieński Janusz; KDW I, nr 402, 423, 429 (wzmianka).

${ }^{61} K D W \mathrm{I}, \mathrm{nr} 429$. 
$1290,1298,1301,1309)^{62}$. Na szczególną wszakże uwagę zasługuje kierunek jego działań. Zarówno w sferze spraw administracyjno-kościelnych, jak też w życiu politycznym, był gorącym rzecznikiem i protagonistą zjednoczenia Polski. Zdawał sobie jasno sprawę z zagrożeń języka i kultury polskiej, jakie niósł z sobą napływ osadników i duchownych niemieckich na ziemie polskie i programowo podejmował środki przeciwdziałajace. W jego statutach synodalnych pojawia się wymóg odmawiania w czasie mszy wyznania wiary, "Ojcze nasz" i „Zdrowaś Mario”, a w miarę możliwości wygłaszania Ewangelii, w języku polskim (1285), zaś co do szkół wszystkich typów - ustanawiania takich tylko ich rektorów, którzy znaliby język polski i po polsku mogli komentować autorów $(1285,1287)$. Jakub zwracał uwage Stolicy Apostolskiej na zagrożenia, jakie ponoszą w Polsce ecclesiastica libertas i prawa kościelne per gentis Theutonicae ingressum, a mial na uwadze zarówno niemieckich osadników, jak też rycerzy i duchownych, zwłaszcza mnichów $(1285)^{63}$.

Arcybiskup Jakub Świnka czynnie zadokumentował to swoje patriotyczne stanowisko, wlączając się w spór biskupa wrocławskiego Tomasza II z Henrykiem IV Prawym (Probusem). Skoro księcia poparli mieszczanie niemieccy i franciszkanie, którzy odłączyli się od polskiej prowincji kościelnej, Świnka stanął po stronie Tomasza $\mathrm{II}^{64}$. Racje narodowe wzięły górę nad kościelnymi, gdy dwukrotnie wytoczyl proces kanoniczny zniemczałemu biskupowi krakowskiemu Janowi Muskacie (1301, 1306), zagorzałemu zwolennikowi Przemyślidów, biorąc wyraźnie w tej tak znanej „sprawie Muskaty” stronę Władysława Lokietka ${ }^{65}$. Podobny wydźwięk ideowy miała szczególna opieka Świnki nad archidiakonatem słupskim arcybiskupstwa gnieźnieńskiego i archidiakonatem pomorskim biskupstwa włocławskiego, zagrożonymi przez napór niemczyzny ${ }^{66}$. Bronił przynależności biskupstwa chełmińskiego do prowincji gnieźnieńskiej ${ }^{67}$.

Niewątpliwy był udział Jakuba Świnki w doprowadzeniu do koronacji Przemysława II. Jego sukcesem musiała być zgoda na ten akt papieża Bonifacego VIII, on $z$ calą pewnością urobil przychylna dla sprawy opinię przynajmniej w sferach kościelnych Polski, skoro w koronacji księcia wielkopol-

${ }^{62} \mathrm{~W}$. Abraham, Studia krytyczne do dziejów średniowiecznych synodów prowincjonalnych Kościoła polskiego. Kraków 1917, s. 41-42; KDW I, nr 551; II, nr 654, 03, 922, 928.

${ }^{63} K D W$ I, nr 551, 552a; SPPP I, s. 358; por. W. Abraham, Studia krytyczne, rozdz. V.

${ }^{64}$ T. Silnicki, A. Goląb, Arcybiskup Jakub Swinka..., rozdz. VI.

${ }^{65}$ W. Abraham, Sprawa Muskat. ,Rozprawy Wydz. Hist.-Filoz. AU”. T. 30:1893; J. Wyrozumski, Jan Muskata. PSB. T. 22:1977, s. 291-295.

${ }^{66}$ K. Tymieniecki, Jakub Świnka. W: PSB. T.10:1962-1964, s. 347-349.

${ }^{67} \mathrm{KDW}$ II, nr 734, 798. 
skiego, której dokonal̉ w Gnieźnıe 26 VI 1295, uczestniczyli biskupi poznański, włocławski, lubuski i płocki, a dwaj inni, krakowski i wrocławski udzielili na nią swojej zgody ${ }^{68}$. Mniej jasno przedstawia się jego stosunek do Wladysława Lokietka jako księcia wielkopolskiego $(1296-1300)^{69}$. Nie uwierzył widocznie $w$ jego sukces polityczny, a może także w jego zdolności, skoro gdy go wygnano z Wielkopolski, zgodził się na koronację Wacława II. Nad racjami czysto ideowymi wzięły tu chyba górę racje pragmatyczne. Dokonał jego koronacji zapewne w przeświadczeniu, że ma on większe szanse na zjednoczenie Polski ${ }^{70}$. I istotnie rodząca się jedność polityczna Polski i leżący u jej podstaw wzrost świadomości narodowej były w dużym stopniu dziełem wielkiego arcybiskupa ${ }^{71}$.

Zmarł w 1314 r. Był więc jeszcze świadkiem powrotu Łokietka do jego kujawskiej ojcowizny i do Krakowa, zawładnięcia przez niego Pomorzem Gdańskim i Wielkopolska. Nie był to triumf polityki zjednoczeniowcj, bo towarzyszyły jej sprawa Muskaty, bunt wójta Alberta i utrata Pomorza Gdańskiego. na rzecz Krzyżaków. Koronacji Łokietka Jakub Świnka nie dożył. Nie dożył jej też jego następca na stolicy arcybiskupiej Borzysław. Ten, choć tylko przez trzy lata zarządzał polską prowincja kościelna, w tym większość sił i czasu musiał poświęcić uzyskaniu konfirmacji papieskiej, pokazał się wszakże kontynuatorem Jakuba Świnki w obronie ziem polskich przed naporem niemieckim i w polityce zjednoczeniowej. Efektem jego zabiegów była bulla Jana XXII z 1317 r. nakazująca powrót diecezji kamieńskiej pod obediencję Gniezna $^{72}$ i inna $z$ tegoż roku zmierzająca do restytucji Kościołowi polskiemu wszelkich dóbr i obiektów kościelnych przez kogokolwiek zagarniętych ${ }^{73}$. W stosowanej przez niego argumentacji za przynależnością utraconych ziem do polskiej prowincji kościelnej pojawia się świętopietrze. Argument ten nie był obcy Jakubowi Śwince ${ }^{74}$.

Kierunek polskiej polityki kościelnej, zmierzajacej do restytucji Królestwa i do rewindykacji terytorialnych kontynuowal Janisław, mianowany arcybiskupem gnieźnieńskim przez Jana XXII. Prawo takie dawala papieżowi okoliczność, że poprzednik Janisława Borzysław zmarł apud Sedem Apostolicam, a sprawę ułatwilo i przyśpieszyło to, że Janisław w tej samej podróży

${ }^{68}$ Rocznik kapituly poznańskiej. W: MPH seria II. T. 6, s. 53.

${ }^{69}$ E. Długopolski, Wladyslaw Lokietek na tle swoich czasów. Wrocław 1951, s. 40.

${ }^{70}$ W. Karasiewicz, Jakub II Świnka arcybiskup gnieźnieński 1283-1314. Poznań 1948, s. 115 .

${ }^{71}$ R. Grodecki, Powstanie polskiej świadomości narodowej. Katowice 1946, rozdz. III.

${ }^{72} \mathrm{KDW}$ II, nr 991

${ }^{73}$ Tamże, nr 992.

${ }^{74} K D W \mathrm{I}, \mathrm{nr} 552 \mathrm{a}$. 
arcybiskupa uczestniczył i był już Janowi XXII znany. W bulli nominacyjnej wszakże Janisław występuje jako electus Gnesnensis ${ }^{75}$, co oznacza, że decyzja papieska nie byla arbitralna, że między datą śmierci Borzysława (30 VI 1317) a data owej bulli nominacyjnej czy prowizyjncj (7 XI 1317) zdołano się porozumieć z Gnieznem i kapituła albo potwierdziła zamysł Stolicy Apostolskiej, albo go zainspirowała.

Jeżeli - jak się domyślamy - celem ostatniej podróży Borzysława do Awinionu było pozyskanie zgody na koronację Lokietka, to Janislaw w tych staraniach uczestniczył. Jemu przypadł zatem w udziale sukces w postaci koronacji Lokietka, na który pracowali i Jakub Świnka, i Borzysław. On sam również do tego sukcesu się przyczynil, choć nie możemy ująć zasług w tej ostatniej fazie starań biskupowi wloclawskiemu Gerwardowi. Pytanie tylko, dlaczego ów sukces polityczny, osiagnięty w dużej mierze przez arcybiskupów gnieźnieńskich, swój spektakularny final w postaci uroczystego aktu koronacyjnego znalazł nie w archikatedrze gnieźnieńskiej, ale w krakowskiej. Chodziło zapewne o zastrzeżenie, które zrobila Stolica Apostolska w bulli zezwalajacej na koronację, że mianowicie nie naruszy ona niczyich praw ${ }^{76}$. Wobec roszczeń luksemburskich do tronu polskiego bezpieczniej było dokonać koronacji w Krakowie, stosując wykładnię zawężajaca pojęcia Polonia, tzn. odnosząc je do Wielkopolski. Jeżeli istotnie tak było, to mamy tu do czynienia z pragmatyzmem, któremu dano pierwszeństwo przed ambicjami i aspiracjami Gniezna. Te same racje mogły zaważyć na dokonanej również za pontyfikatu Janisława koronacji Kazimierza Wielkiego. Inaczej mówiąc, sprawa roszczeń luksemburskich do tronu polskiego nie została jeszcze w 1333 r. załatwiona. Kazimierz Wielki być może poczynił na przyszłość pewne obietnice co do przywrócenia Gnieznu rangi miejsca koronacyjnego, bo po śmierci ostatniego króla Piasta upomnieli się o to i Jarosław ze Skotnik Bogoria, i panowie wielkopolscy, czego - jak wiadomo - Ludwik nie spelnit ${ }^{77}$.

Janisław stanął na pewno przy królu w jego polityce rewindykacyjnej w stosunku do Zakonu. Za jego pontyfikatu odbyły się wszak dwa procesy kanoniczne przeciwko Zakonowi $(1320,1339)$, a w pierwszym z nich Janisław byl jednym z trzech sędziów powolanych przez Stolicę Apostolską ${ }^{78}$. W sferze stosunków wewnątrzkościelnych mamy do odnotowania odbyte za jego czasów trzy synody prowincjonalne $(1326,1330,1333)^{79}$.

\footnotetext{
${ }^{75}$ KDW II, nr 995.

${ }^{76}$ VMP I, nr 226.

${ }^{77}$ Kronika Jana z Czarnkowa. W: MPH. T. 2, s. 644

${ }^{78}$ Zob. przyp. 21.

${ }^{79}$ KDW II, nr 1061; SPPP I, s. 397-407.
} 
Wielka była rola Jaroslawa ze Skotnik Bogorii. Zachodzi szczególna spójność w działaniach wielkiego króla Piasta i uczonego prawnika, głowy Kościola polskiego w latach 1342-1374. Jarosław statystowal we wszystkich niemal ważniejszych wydarzeniach tego panowania. Niejedno inicjował lub współtworzył. Długi pontyfikat obfitował nie tyle w spektakularne, ile w trwałe i fundamentalne osiagnięcia. Dobry gospodarz, lokował wiele wsi na prawie niemieckim, a paru osadom nadal prawo miejskie (Żnin, Kamień koło Nakła) ${ }^{80}$. Wzniósł zamki murowane w Lowiczu, Uniejowie, Opatowie i Kamieniu, a murowane dwory w Łęczycy, Krakowie, Wieluniu, Kaliszu, Gnieźnie i Uniejowie. Był budowniczym nowej katedry w Gnieźnie, gdy Kazimierz Wielki budowal katedrę krakowską; jemu zawdzięcza początek szeregu murowanych kościołów ${ }^{81}$. Pozyskał wielki przywilej królewski dla Kościoła polskiego $(1357)^{82}$, byl twórca zbioru polskiego prawa synodalnego (1357), tzw. synodyku $^{83}$ i współtworzył kodeks prawa ziemskiego, czyli tzw. statuty Kazimierza Wielkiego ${ }^{84}$.

Współpraca Jarosława Bogorii z królem datuje się jeszcze sprzed lat jego arcybiskupiego pontyfikatu. Już bowiem na procesie Polski z Zakonem w 1339 r. był on pelnomocnikiem królewskim ${ }^{85}$. Wcześniej uczestniczył także w innych aktach politycznych króla ${ }^{86}$. Jako arcybiskup bral udzial w zawarciu pokoju wieczystego z Zakonem (1343) i w szeregu innych pertraktacji i ukladów ${ }^{87}$. Sukcesem Gniezna i osobiście Jarosława było obalenic przez Polskę dążeń Karola IV Luksemburczyka, zmierzajacych do wyłączenia diecezji wrocławskicj z prowincji kościelnej polskiej i włączenia jej do utworzoncj w 1344 r. archidiecezji praskiej (1351), co moglo się wydawać naturalną konsekwencją inkorporacji Śląska do Korony czeskiej $(1348)^{88}$. Nie powiodła się natomiast podjęta znowu po latach przez Jarosława próba przywrócenia zwierzchności Gniezna nad biskupstwem kamieńskim. Sprawa toczyła się przez szereg lat (1345-1349 i 1360-1371), ale zakończyła się utwierdzeniem

\footnotetext{
${ }^{80}$ Z. Kowalska-Urbankowa, Jarosław ze Skotnik..., rozdz. IV.

${ }^{81}$ Kronika Jana z Czarnkowa. W: MPH. T. 2, s. 672-673.

${ }^{82} \mathrm{KDW}$ III, 1354

${ }^{83}$ SPPP I, s. 331-416 (z uzupełnieniami).

${ }^{84}$ Statuty Kazimierza Wielkiego. Oprac. i wyd. O. Balzer. Poznań 1947 (statut małopolski); cz. II Statuty wielkopolskie. Oprac. i wyd. L. Lysiak. Warszawa-Poznań 1982.

${ }^{85}$ Lites ac res gestae inter Polonos Ordinemque Cruciferorum, wyd. 2. T. 1. Poznań

${ }^{86} \mathrm{DKiM}, \mathrm{s} .139, \mathrm{nr} 71$.

${ }^{87}$ KDW II, nr 1223; por. S. Szczur, Uwagi o dziatalności dyplomatycznej arcybiskupa gnieźnieńskiego Jaroslawa z Bogorii. „Nasza Przeszlość”. T. 67. 1987, s. 237-247.

${ }^{88}$ Z. Kaczmarczyk, Monarchia Kazimierza Wielkiego. T. 2. Poznań 1947, s. 54-56; por. też $K D W$ III, nr 1439
} 1890, s. $66-68$. 
zasady bezpośredniej podległości biskupstwa Stolicy Apostolskiej ${ }^{89}$. Miał arcybiskup Jarosław swój osobisty udzial w tworzeniu lacińskiej organizacji kościelnej na Rusi halicko-włodzimierskiej, włączonej przez Kazimierza Wielkiego do Polski. Dotyczyło to zwłaszcza utworzenia biskupstwa lacińskiego we Lwowie (1363-1368). Sprawa wprawdzie natrafiła na trudności ze strony biskupstwa lubuskiego, ale zakończyła się po myśli Kazimierza Wielkiego i arcybiskupa gnieźnieńskiego ${ }^{90}$.

Miał wreszcie Jaroslaw Bogoria swój bardzo istotny wkład w utworzenie Akademii Krakowskicj. Ten wychowanek Uniwersytetu Bolońskiego, niegdyś rektor jego zaalpejskiej korporacji, godnie upamiętniony w samej Bolonii, zapewne zainspirował przedsięwzięcie i pozytywnie zaopiniował zamysł, gdy się Stolica Apostolska o to do niego zwrócila, choć być może nie do końca zachował wplyw na kształt krakowskiego Studium Generale ${ }^{91}$.

Janko z Czarnkowa napisał o nim, że ,go czcili i ojcowska miłością otaczali królowic, ksiązęeta i dostojnicy królestw Polski, Wẹgier i Czech, jak ojca i męża największej laskawości"

Nie miał tego szczęścia ścisłego współdziałania z królem następca Jarosława ze Skotnik, także bolończyk, doktor dekretów Janusz Suchywilk. Na tron arcybiskupi wstapił jeszcze za życia swego poprzednika, gdy ten z powodu utraty wzroku muisiał z arcybiskupstwa ustapić. Został przez nicgo w pewnym sensie desygnowany, ale Ludwik, choć go zrazu poparł, czynił mu trudności w Stolicy Apostolskiej ${ }^{93}$. Uwikłany od początku w sprawy polityczne, pozostał niemal do końca swoich dni, bo do 1381, w mniej lub więcej jawnej opozycji w stosunku do planu Ludwika, aby sukcesję na tronie polskim zapewnić jednej ze swoich córek. Był wszak zwolennikiem sukcesji Kaźka słupskiego, wnuka Kazimierza Wielkiego, uczestniczyl zapewne w usynowieniu go przez ostatniego króla Piasta, w dokonaniu na jego rzecz zapisu testamentowego, który go wprowadzał w królewską ojcowiznę, a jako kanclerz krakowski, czlonek rady królewskiej i zaufany Kazimierza stał się egzekutorem jego testamentu ${ }^{94}$, obalonego zreszta w tej ważnej politycznie cześsi u początków panowania Ludwika. Janko z Czarnkowa, który byl archidiakonem gnieźnieńskim, zatem osobiście stykał się z Januszem, niezbyt przychylne pozostawił

${ }^{89}$ S. Nowogrodzki, Walka o biskupstwo kamińskie za Kazimierza Wielkiego. „Jantar”. R. 2:1938, z. 4, s. 209-218.

${ }^{90} \mathrm{KDW}$ III, nr 1492, 1613; W. Abraham, Powstanie organizacji Kościola lacinskiego na Rusi. Lwów 1904, s. 256-268.

${ }^{91}$ S. Krzyżanowski, Poselstwo Kazimierza Wielkiego do Awinionu i pierwsze uniwersyteckie przywileje. „Rocznik Krakowski” 4:1900, s. 58-59.

${ }^{92}$ MPH. T. 2, s. 673.

${ }^{93}$ Kronika Jana z Czarnkowa. W: MPH. T. 2, s. 653.

${ }^{94}$ Tamże, s. 639-642. 
o nim świadectwo. Zarzucał mu nepotyzm, surowość wzgiędem duchownych i ich uciskanie nadmiernymi świadczeniami, rozdanie krewniakom kosztowności arcybiskupich, pozostawienie arcybiskupstwa w uciążliwej sytuacji itp. ${ }^{95}$ Wiemy jednak skądinąd, że zarządzał prowincją kościelną w warunkach wyjatkowo trudnych, w stanie anarchii, wojny domowej w Wielkopolsce i silnej polaryzacji stanowisk politycznych ${ }^{95}$. Statutowo uregulował przecież funkcjonowanie kapituły gnieźnieńskiej (1375) i mimo że pontyfikat jego trwał zaledwie 8 lat, odbyl trzy synody prowincjonalne $(1376,1378,1380)^{97}$.

Znaczaca zasługa Janusza Suchywilka było sfinalizowanie sporu z biskupstwem lubuskim w sprawie zwierzchności kościelnej nad Rusią halickowłodzimierska ${ }^{98}$ i utworzenie nuskiej prowincji kościelnej z siedzibą arcybiskupią w Haliczu i z sufraganiami w Przemyślu, Włodzimierzu i Chełmie (1375). Wiadomo, że z pełnomocnictwa Stolicy Apostolskiej działał w tej sprawie Janusz $z$ udziałem biskupów krakowskiego i płockiego ${ }^{99}$. Być może w tej fazie rodzenia się arcybiskupstwa ruskiego aspirował Janusz do godności prymasowskicj i miał pewną szansę na uzyskanie zwierzchności nad tym arcybiskupstwem $z$ ramienia Kościoła polskiego. Komplikację stanowiło wszakże to, że - wbrew dawniejszym zobowiązaniom - Ludwik budował lączność Rusi z Węgrami, a nie z Polska ${ }^{100}$.

Pobieżny siła rzeczy przegląd dokonań i roli arcybiskupów gnicźnicńskich w latach 1199-1382 daje świadectwo dużej ich prężności i odpowiedzialności w działaniu, zarówno $w$ sferze administracyjno-kościelnej, jak i politycznej. Większość z nich, czy może nawet wszyscy, stawali na wysokości zadań, które nakladały na nich niełatwe z reguły czasy. Nie chciałbym się wypowiadać, czy były wśród prezentowanych arcybiskupów postacie świątobliwe, bo brak mi do tego dostatecznych przesłanek. Nie brakło wszakże ani patriotyzmu, ani żarliwej troski o kraj i o Kościół polski. Nie brakło także szerszych politycznych horyzontów i mądrości. Wydaje się też, że nie wysokie rodowe koneksje, nie przekupstwo i nie nepotyzm decydowały o wyborze na arcybiskupstwo, a w każdym razie nie majoryzowały one intencji czystych i uzdolnień. Nie było co prawda wówczas despotycznej władzy, która stawiałaby konformizm i posłuszeństwo przed madrościa i energia. Stwarzało to względnie korzystny dla Kościoła i dla państwa układ, który pozwalał rozwijać talenty i czynić z nich godziwy i stosowny do okoliczności użytek.

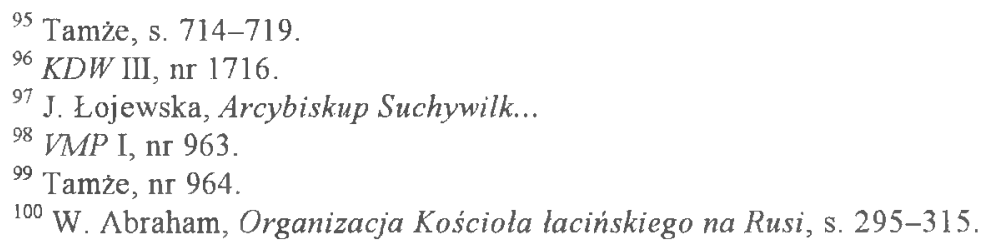




\section{WYKAZ SKRÓTÓW}

DKiM - Dokumenty kujawskie i mazowieckie przeważnie z XIII wieku. Wyd. Ul an o w s k i. Kraków 1887

KDKK - Kodeks dyplomatyczny katedry krakowskiej. Wyd. F. P i e k o s i ń s k i. T. 1. Kraków 1874

KDM - Kodeks dyplomatyczny Matopolski. Wyd. F. P i e k o s i ń s k i. T. 1. Kraków

KDW - Kodeks dyplomatyczny Wielkopolski. T. 1. Poznań 1877, t. 2. Poznań 1878, t. 3. Poznań 1879

MPH - Monumenta Poloniae Historica, t. 2 (wyd. A. B i e lo w s k i). Lwów 1872, t. 3. Lwów 1878

MPV - Monumenta Poloniae Vaticana. Wyd. J. P t a ś n i k. T. 1. Kraków 1913, t. 3. Kraków 1914

PSB - Polski Stownik Biograficzny

SPPP - Starodawne prawa polskiego pomniki. T. 1. Wyd. A. Z. H e 1 c e 1. Warszawa 1856

VMP - Vetera monumenta Poloniae et Lithuaniae historiam illustrantia. Wyd. A. T h e i n e r. T. 1. Rzym 1860 